\title{
滴の蒸発に関する㬰驗 *
}

\section{（蒸発の研究 VI）}

\section{1 緒 矛}

$$
\text { 获原明 二** }
$$

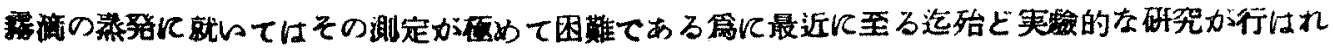

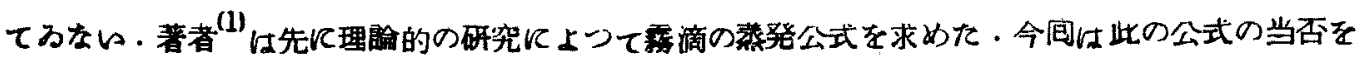
刵定する目的で一つの実驗子陚みたのてその結果に就いて述べてみ上らと思ふ一昨年北大の吉田 数授 に述ベる事にする

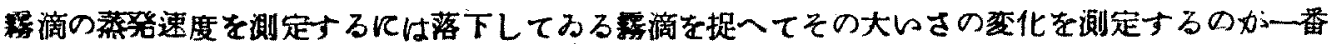

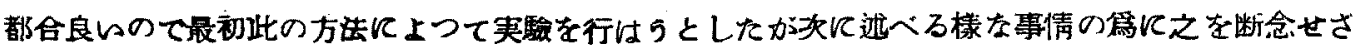

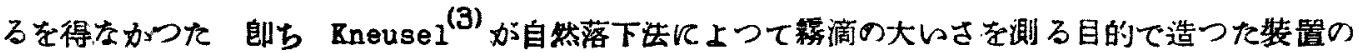

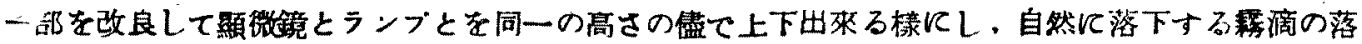

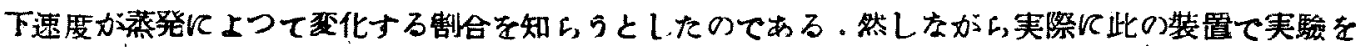

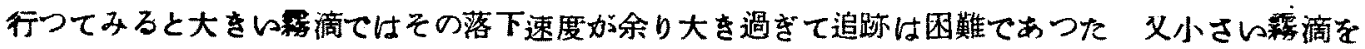

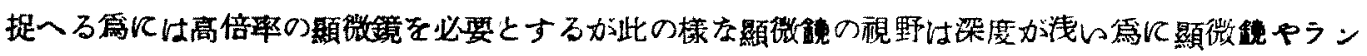

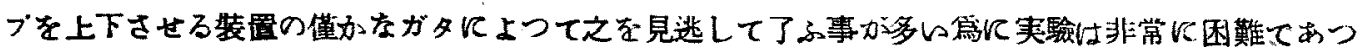

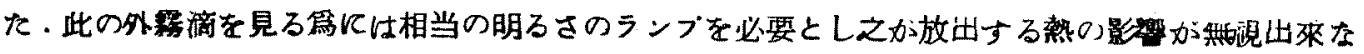
ら事などの急に遂に此の方法を断念せさるを得なかつたのてるる

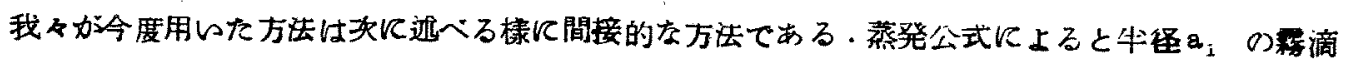

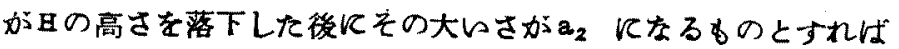

$$
H=\frac{. q}{18 k \mu\left(C_{0}-C_{\infty}\right)}\left\{a_{1}^{4}\left(1-\frac{4}{7} \alpha_{1} a_{1}\right)-a_{2}^{4}\left(1-\frac{4}{7} \alpha_{2} a_{2}\right)\right\}
$$

て與へられる・文此の落下に姴した時間は

$$
T-\frac{1}{2 k\left(C_{0}-C_{\infty}\right)}\left\{a_{1}^{2}\left(1-\frac{2}{5} \alpha_{2} a_{1}\right)-\alpha_{2}^{2}\left(1-\frac{2}{5} \alpha_{2} a_{2}\right)\right\}
$$

ておるて১に 表面及び空氣中の水蒸氣密度： $\alpha_{1}-\frac{\mu_{1}}{2 k} ; \mu_{1}-a_{1}$ の)落下速度 $-\frac{2 g}{9 \mu} a_{1}^{2}$ でる.今之等二つの式 * S. Ogiwara: Bxperimental Studies on the Evaporation of Fog Particles (Studies on Evaporation Part VI)

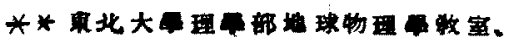

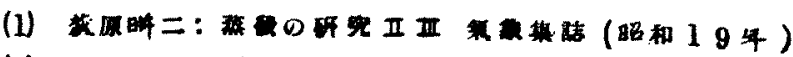

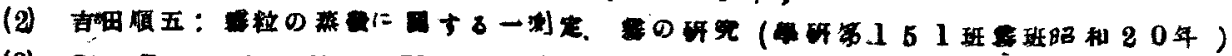

(3) St. Knouse 1: Met. 2s. 52. (1935) 


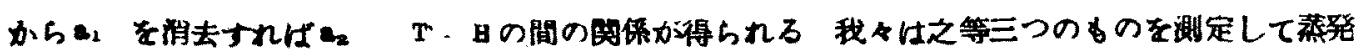
公式の当否を㸪定しょのとしたのておる

82 実驗の方法

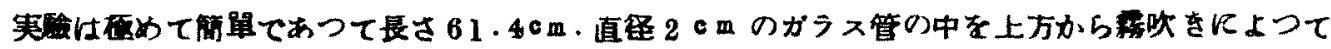

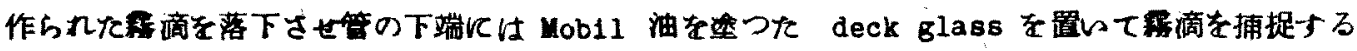

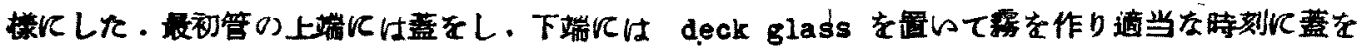

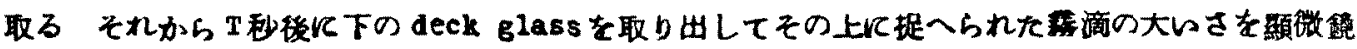
て测定するのてある

今時到の测り初めに丁度管の上端にあつた滴が丁度T秒後に deck glass の上に落下した。

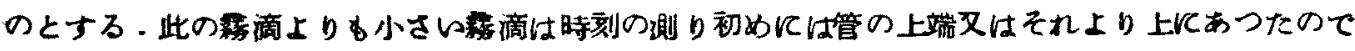

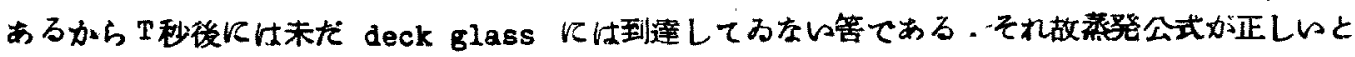

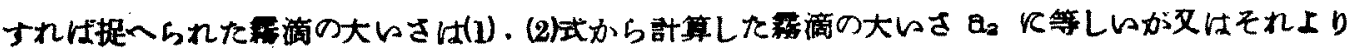

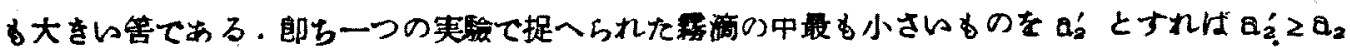

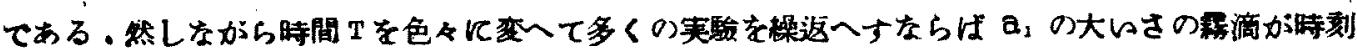

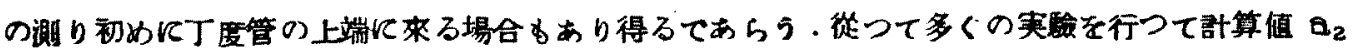

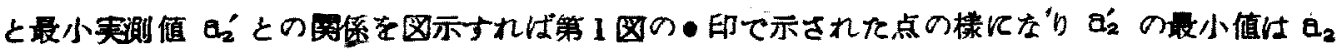

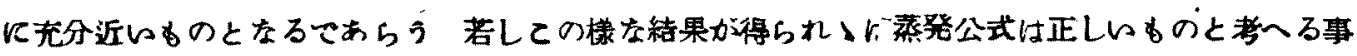

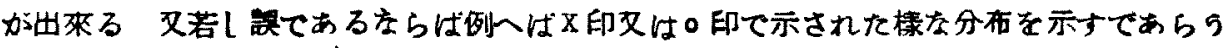

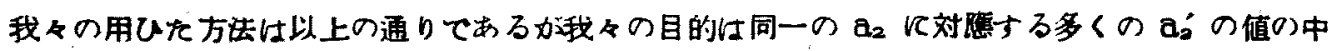

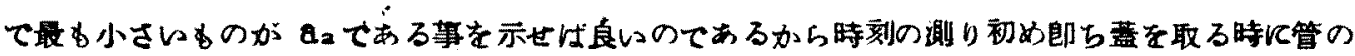

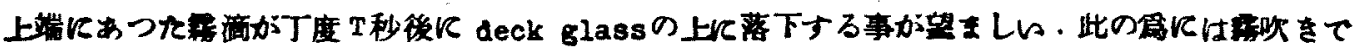

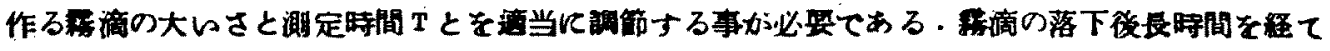

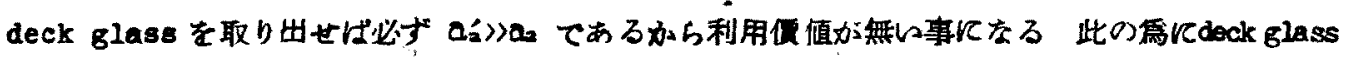
の直ぐ上イ别の deck glassを青を下の glass と入れ代りに之と管の下に入れ下のすのを取去つ

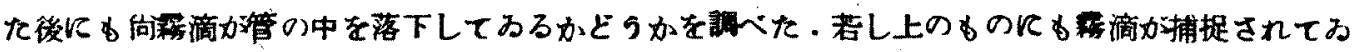
るならば下の glass に捕捉された露滴は落下後余り時間を経過してかないてあらのと云ふ想像が

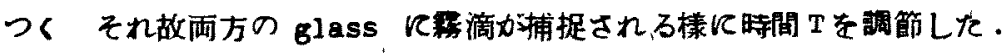

\section{\$3実跲の結果}

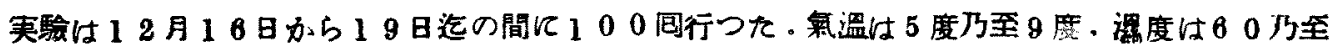

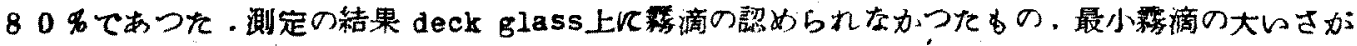

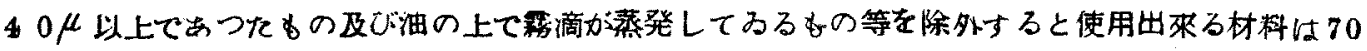

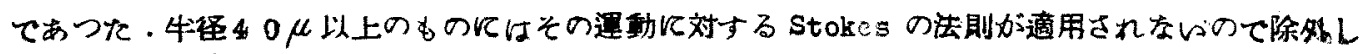

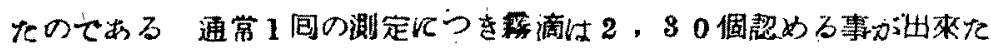




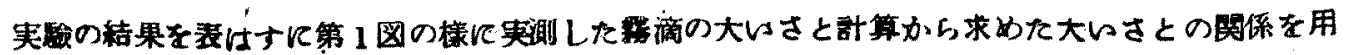

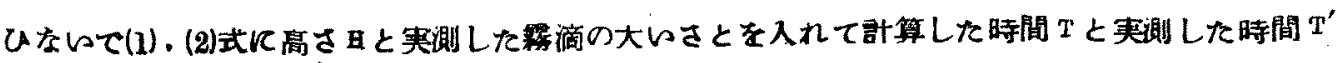

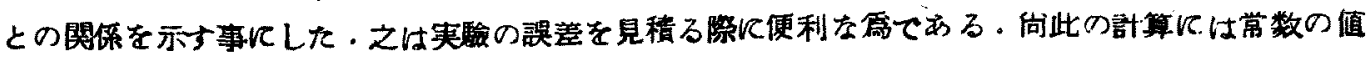
として kー0.237, $\mu-175 \times 10^{-6}$ ( $7^{\circ} 00$ 檤)を用した

維軸に $T^{\prime}-T$, 橫軸に測定した露滴の 第 I図 第 2 因 牛烽 $\mathrm{a}_{2}$ を取つて実驗の結果を图示う ると第 2 图の侎になる 又実驗結果の 例を第 1 表に示した・T片の余り大 さいるの利用槚值坊少いのて第2図 には+20秒以上の60(17回)を
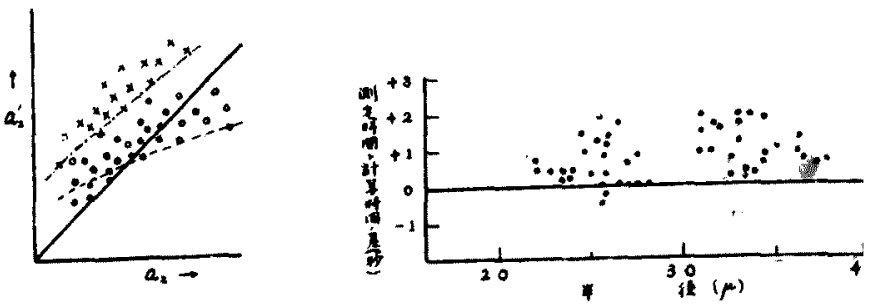
第 1 票 12 月 16 日

\begin{tabular}{|c|c|c|c|c|c|c|c|c|c|c|}
\hline 番号 & 做测踪副 & 氣梄 & 溜度 & $\left(C_{0}-C_{\infty}\right) \times 10^{0}$ & $\alpha_{2}$ & (湘定) & 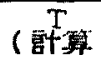 & $a_{2}$ & $\frac{H}{\mu_{2}}$ & \\
\hline 1 & $10^{\mathrm{n} 22^{\mathrm{m}}}$ & 5.5 & 68 & 1.23 & $50<$ & $6 \cdot 3$ & & & & \multirow{10}{*}{ 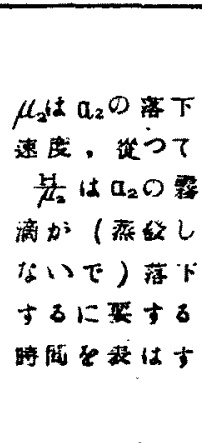 } \\
\hline 2 & 28 & 5.7 & 70 & $1 \cdot 18$ & 26 & 6.0 & 6.0 & 33 & $7 \cdot 2$ & \\
\hline 3 & 33 & $5 \cdot 7$ & 71 & $1 \cdot 19$ & 25 & $6 \cdot 1$ & $\theta \cdot 1$ & 32 & $7 \cdot 8$ & \\
\hline 4 & 40 & $5 \cdot 9$ & 68 & 1.25 & 27 & $5 \cdot 4$ & $5 \cdot 4$ & 33 & $6 \cdot 7$ & \\
\hline 5 & 45 & $5 \cdot 0$ & 68 & $1 \cdot 25$ & 25 & $5 \cdot 6$ & $6 \cdot 1$ & 32 & 75 & \\
\hline 6 & 53 & 5.9 & 68 & $1 \cdot 25$ & 31 & 5.8 & $4 \cdot 1$ & 35 & $5 \cdot 2$ & \\
\hline 7 & $11 \mathrm{~h} 10 \mathrm{~m}$ & $6 \cdot 1$ & 68 & $1 \cdot 27$ & 27 & $5 \cdot 3$ & $5 \cdot 3$ & 33 & 6.7 & \\
\hline 8 & 16 & $\begin{array}{ll}6 & 1\end{array}$ & 68 & 1.27 & & $5: 8$ & & & - & \\
\hline-9 & 18 & $6 \cdot 1$ & 68 & 1.27 & 36 & $7 \cdot 2$ & 3.4 & & ii.s & \\
\hline 10 & 25 & 6.1 & 68 & $1 \cdot 27$ & & & & & & \\
\hline
\end{tabular}

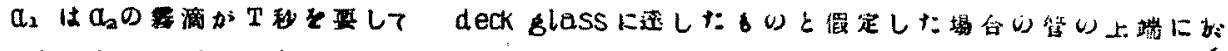
ける大以る(部筆)

$a_{2}$ 虹实制植

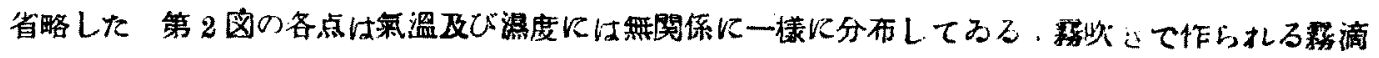

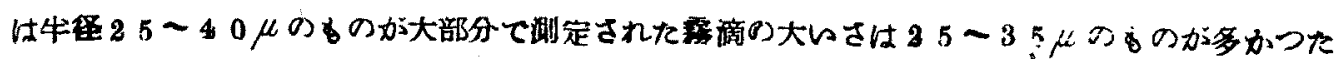

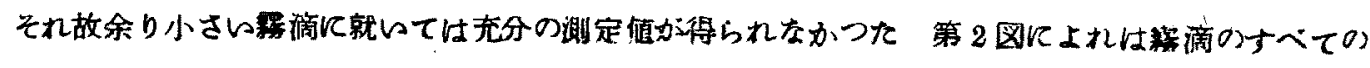

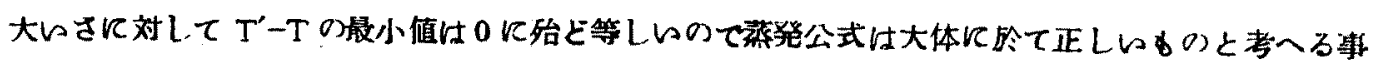
が出來るが台その結果に対しては多くの考察を必要とする

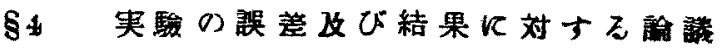

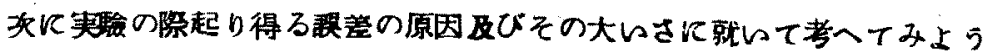

\section{(1) 硝子管內の氧流の影得}

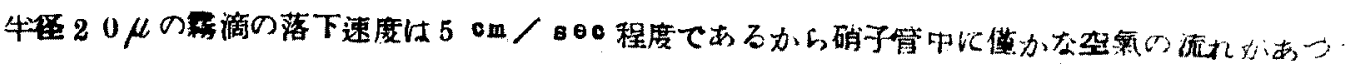

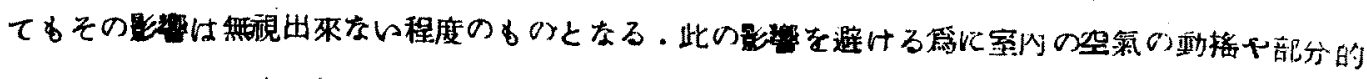

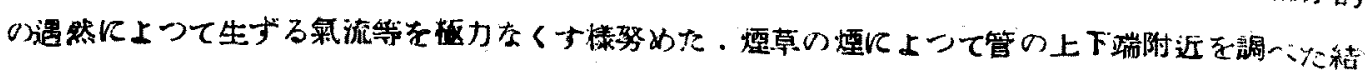
果で此の影触全く認かられなかつた 


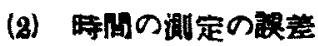

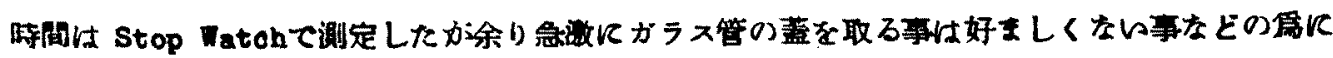

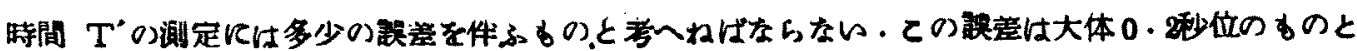
思杜れる。

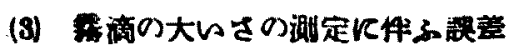

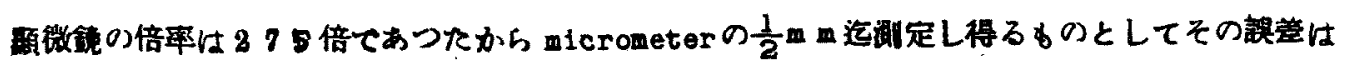

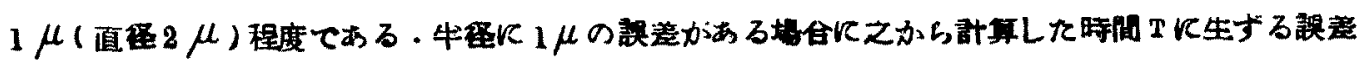

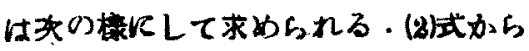

$$
\frac{d T}{d a_{2}}=\frac{1}{k\left(C_{0}-C_{\infty}\right)}\left(a_{1} \frac{d a_{1}}{d a_{2}}-a_{2}\right)
$$

又(1)式加的 $a_{1}^{3} \frac{d a_{1}}{d a_{2}}-a_{2}{ }^{3}=0$

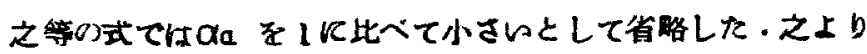

$$
\frac{d T}{d a_{2}}-\frac{\mathfrak{a}_{2}}{k\left(C_{0}-C_{\infty}\right.}\left(\frac{a_{3}^{2}}{a_{1}^{2}}-1\right)
$$

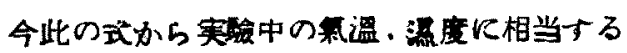

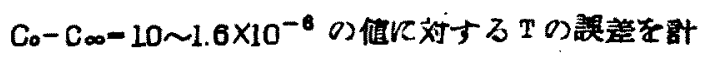

\begin{tabular}{|c|c|c|c|c|}
\hline $\begin{array}{l}\alpha_{20}^{c_{0}-c_{\infty}} 1 \cdot 0 \\
20 \mu-0 \cdot 43\end{array}$ & $\begin{array}{r}1.8 \\
-0.38\end{array}$ & $\begin{array}{r}1.4 \\
-0.35\end{array}$ & $\begin{array}{l}1.6 \times 10^{-0} \\
-0.3180 c\end{array}$ & 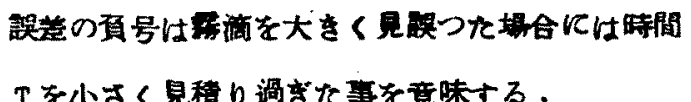 \\
\hline $30 \mu-0.27$ & -0.25 & -0.23 & $-0.22 \leq 00$ & \\
\hline
\end{tabular}

第すると决の梾になる

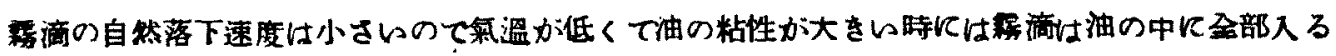

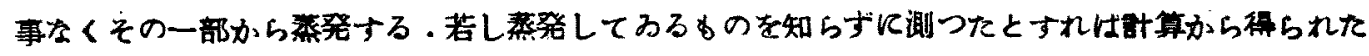

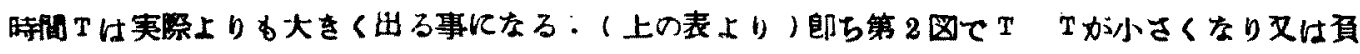

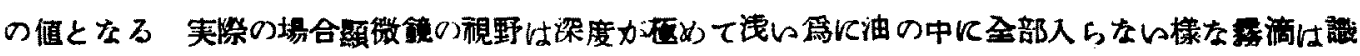

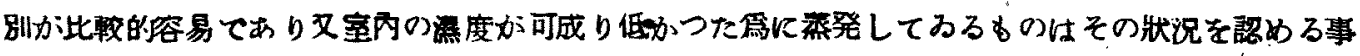

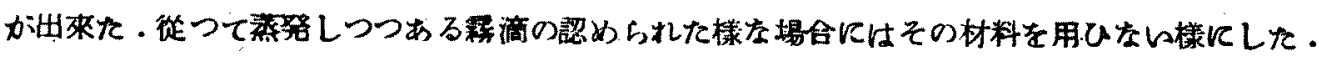

（5）最小滴を見落した場合

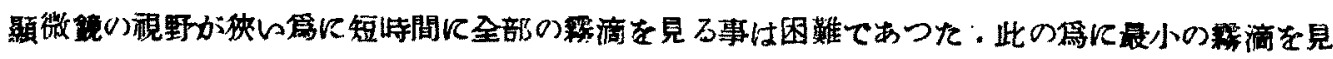

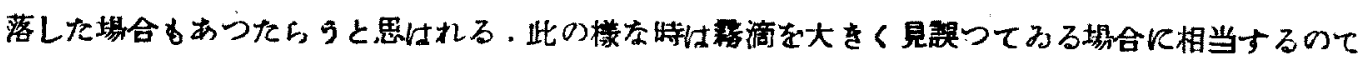

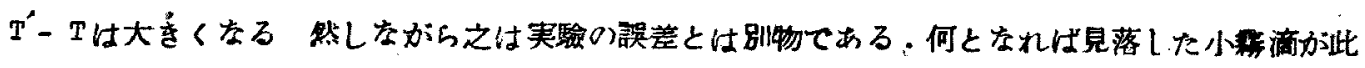

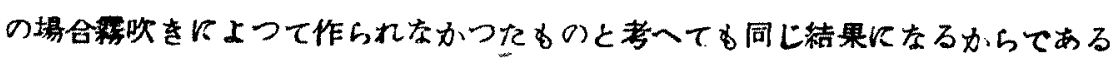

(6) 砣子管內の实㳑及じ瀑度の变化

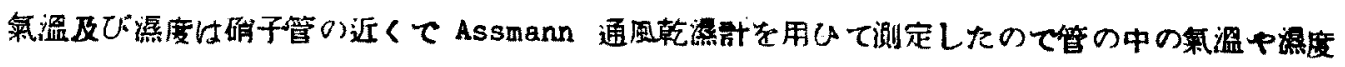

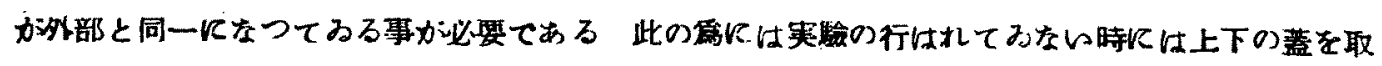

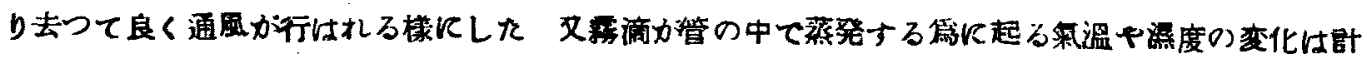
算の結果余り小さくて問题にならない程度てあつた 


\section{(7) 䟢商の盢度}

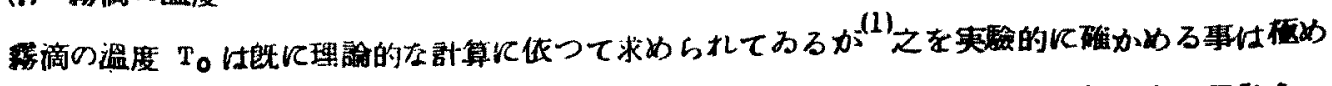

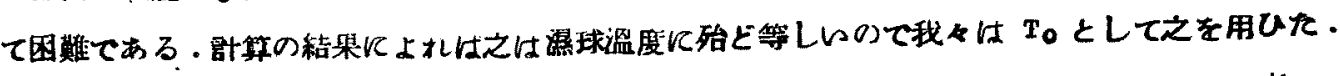

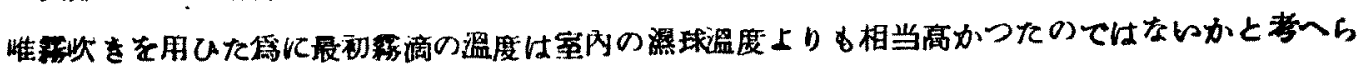

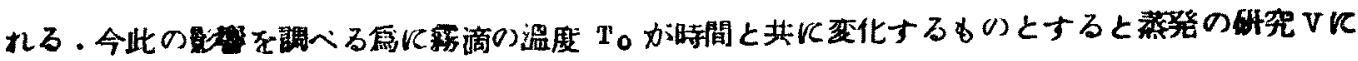

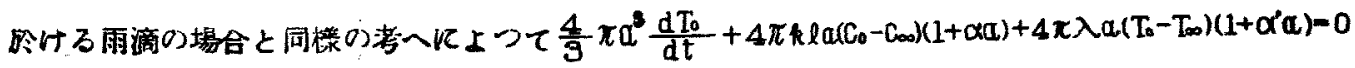

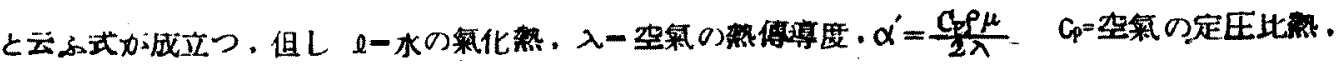

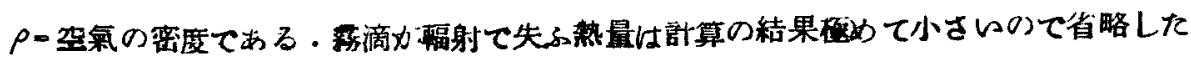

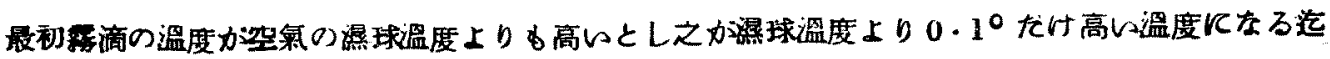

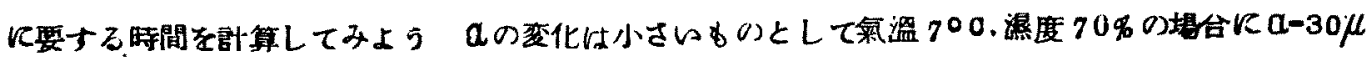
の㶾滴に就いて近似計算を行ふと次の粶になる

\begin{tabular}{|c|c|c|}
\hline 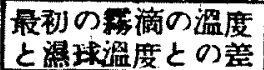 & 所要嘲間 & この間に落下ナる距離 \\
\hline $\begin{array}{l}50^{\circ} \\
10^{\circ} \\
20^{\circ}\end{array}$ & $\begin{array}{l}\text { 約 } \frac{1}{5} \text { 型 } \\
\text { - } \frac{1}{45}= \\
\cdot \frac{1}{4} \text {. }\end{array}$ & $\begin{array}{l}\text { 約 } 2 \text { 糎 } \\
-2.5 \circ \\
\cdot 3 .\end{array}$ \\
\hline
\end{tabular}

㫦此の所要時間は跨滴の牛经の自乘に比 例するので小籍谪てはすつと短时間になる

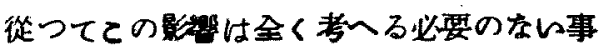
加战つた。

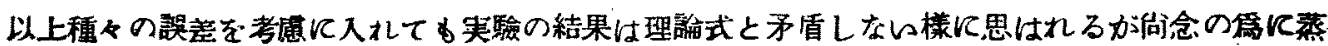
発公式の係数を少しく变へた場合に第 2 図の結果加どの栐に变るもの加を調べてみ上す

蒸発公式

$$
\frac{d}{d t}\left(\frac{4}{3} \pi a^{3}\right)=-4 \pi k a\left(C_{\infty}-C_{\infty}\right)(1+\alpha a)
$$

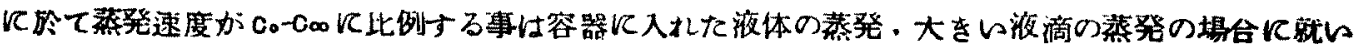

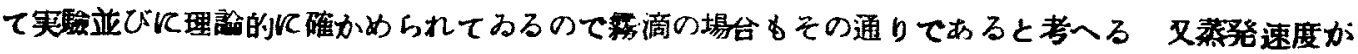

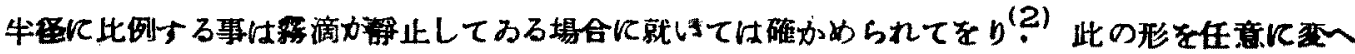

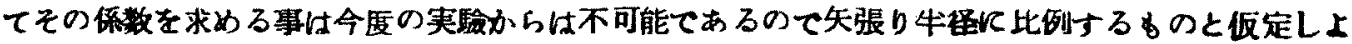

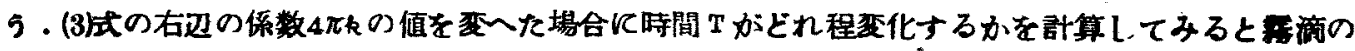

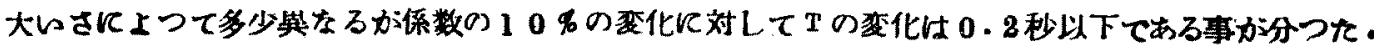

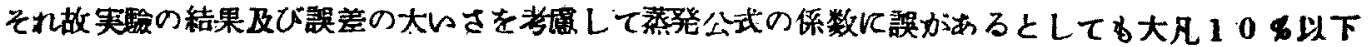
てあると云事事竕る

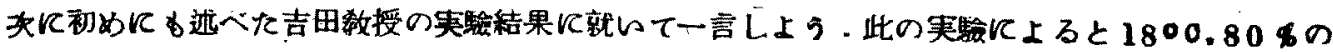

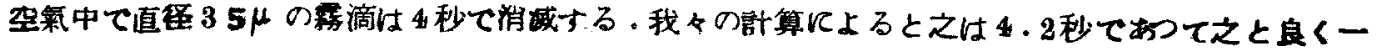

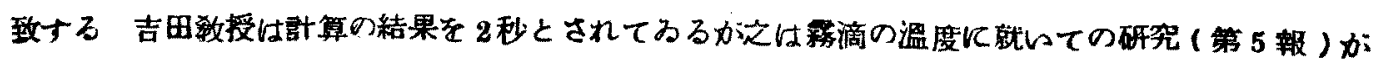

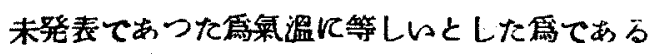

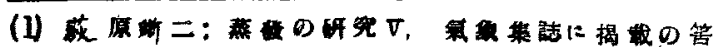

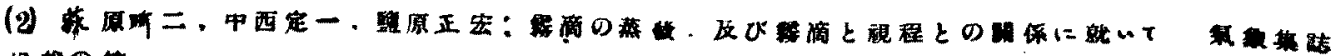

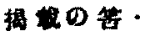


85 結

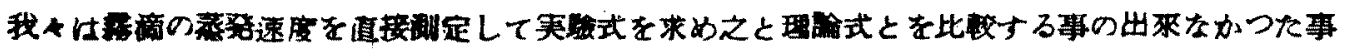

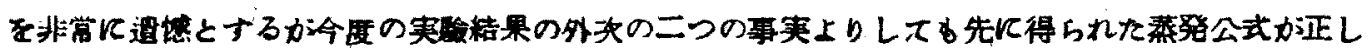
らものと琶めて良いてあらっと思。

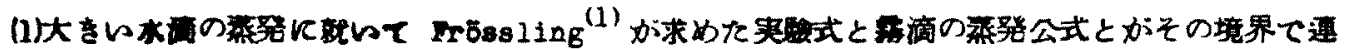

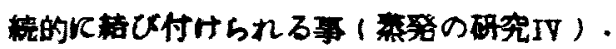

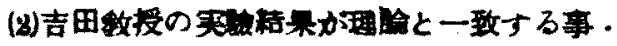

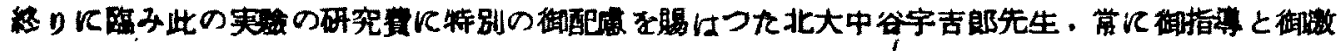

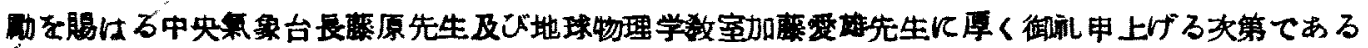

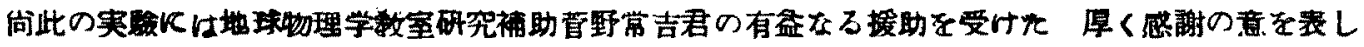
たい.

\section{対流雲中の氣溫並びに击滴の生長に就いて *}

（降水機巧穴呼究Ｉ）

\section{§1粕言}

$$
\text { 获原 }
$$

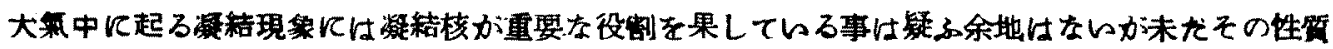

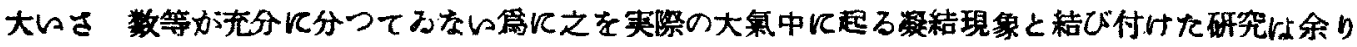

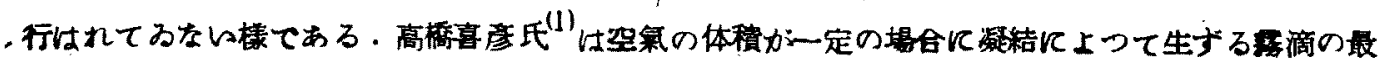

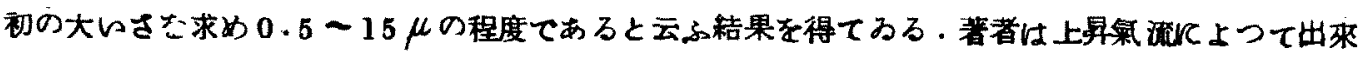

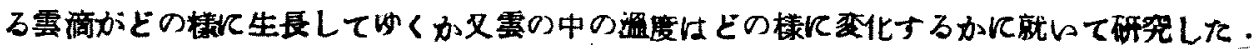

\section{2 筆力的变化の場合}

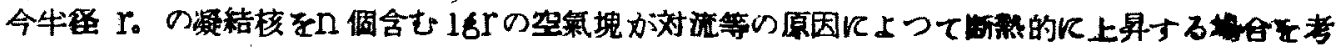

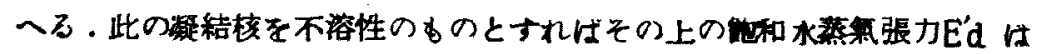

$$
E_{d}^{\prime}=E_{d} e^{\frac{2 \alpha M}{R T_{0} T_{d}}}
$$

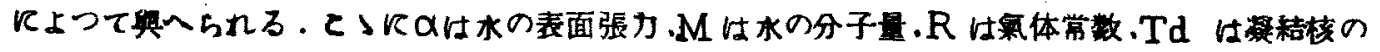

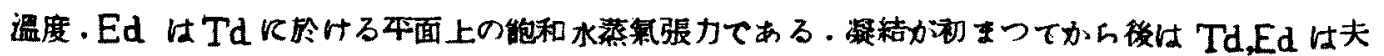
(1) V.Fröseling: thot die Verdunstun fellender Tropien, Beitr. Z. Geophys. $52(1038)$.

* S. Ogivara : On the Temperature of the Air and the Growth of Cloud Particles in Convective Clouds (Studies on the Formation of cloud and Rain. Part I)

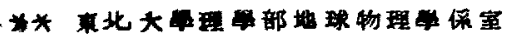

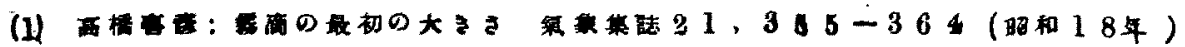

